\title{
Iowa Republicans Organized in 1856
}

\author{
By EMORY H. ENGLISH
}

Examination of the record of events, as presented by several historical authorities upon political movements and parties in Iowa, discloses no support for the recent suggestion that the Republican party was organized at a meeting held in Crawfordsville, in Washington county, Iowa, in February, 1854, or upon any other date.

On the contrary, it is revealed that the meeting, so credited, was in fact a convention of the Free Soil party, one of those political groups that was formed and flourished for awhile about the time the old Whig party was in the throes of dissolution and prior to the advent of the Republican organization.

The Free Soilers met at Crawfordsville, according to dependable authorities, on March 28, 1854, and took action withdrawing the previously nominated gubernatorial candidate of that party, Simeon Waters, and passed resolutions endorsing the Whig candidate for that office, James W. Grimes of Burlington. Brief statements in articles by Iowa historians of note, clearly and concisely outline some details of controlling political events in Iowa in 1854.

Louis Pelzer, historian and teacher at Iowa City, long time editor of the Mississippi Valley Historical Review, wrote an article entitled "The Origin and Organization of the Republican Party in Iowa", appearing in the Iowa Journal of History and Politics, October 1906, Vol. IV, pp. 487-525, in which he said:

On March 28, 1854, the Free Soil Convention (of which Issac Field of Denmark was president) was held at Crawfordsville. Since it was known from previous elections that this party held almost the balance of power, Mr. Grimes was anxious to bring about a concentration of anti-Nebraska sentiment. The Free Soilers, accordingly, withdrew their candidate for governor (Mr. Simeon Waters, who had been pre- 
viously nominated) and adopted resolutions recommending that the members of Free Democracy rebuke the Nebraska swindle by casting their votes for Grimes ... Mr. Grimes now became the champion of all the anti-slavery forces and entered upon the campaign with vigor and determination ...

In the election of August 3, 1854, Mr. Grimes received a majority of 2,123 votes over Curtis Bates, his Democratic opponent. While this campaign and election signalized the death of the old Whig party, it meant the conception of the new Republican party ... it needed only the machinery of organization.

An article by that eminent spiritual and intellectual leader, Dr. William Salter, of Burlington, appearing in the Iowa Historical Record, October 1892, Vol. VIII, No. 4, pp. 337-359, corroborates the action taken and quotes these two declarations:

1. That the object of our suffrages is to elect candidates who will resist the extension of slavery over the territory of the United States, and give the people of Iowa a Maine law.

2. We recommend the Free Democracy to cast their votes for James W. Grimes, of Des Moines county, for Governor, because we believe, if elected, that he will maintain and carry out these principles.

While some members of the Whig party deserted $\mathrm{Mr}$. Grimes, the anti-slavery sentiment of the state rallied in his support, and he was elected by a majority of 2,468 votes. An entire change at once came over the political history of Iowa, and soon followed over the whole country, Mr. Grimes's election being the first prominent movement towards the organization of the Republican party.

In "The Life of James W. Grimes", by Dr. William Salter, p. 33, appears the following:

In February, 1854, Mr. Grimes was nominated by a Convention of the Whig party for Governor of the State. It was the largest State Convention of that party ever held in Iowa, and the last. The following month, March 28th, a Free-Soil Convention, held at Crawfordsville, of which Isaac Field, of Denmark, was president, recommended the Free Democracy to cast their votes for him; and a candidate who had previously been nominated by that party withdrew. The country was violently agitated by a proposition in Congress to declare inoperative and void the prohibition of slavery in those vast regions which have since been constituted into the States of Kansas and Nebraska. Mr. Grimes perceived that 
the proposition involved a crisis in the nation's history, and at once threw himself against it with determined resolution and energy.

In Dr. Salter's Life of Grimes, on p. 115, is quoted the following personal reminiscences by the Rev. Asa Turner, Congregational Pastor at Denmark, 18381868:

I think that $\mathrm{Mr}$. Grimes has done more for Iowa, politically, than any man that ever lived in it. From its first organization as a Territory, the Democracy reigned supreme up to 1854. Our Representatives in Congress were the allies of the slave-power, and carried out its wishes. The Whigs pretended to be antislavery, but were not willing to do anything that would compromise them with their Southern allies. We had a Free-Soil organization, embracing a few voters, and had nominated Simeon Waters as our candidate for Governor, not with any hope of electing him, but to show our strength. In this state of things, Mr. Grimes came over to Denmark and said that if the Free-Soilers would vote for him he would be a candidate for Governor, and assured us that he would be true to the principles we wished should triumph. I believed he would, and that he could make our principles triumph. The Free-Soilers, after free and full discussion, voted to intrust in his hands the interests of our organization, and the principles we had been laboring to establish. We should not have been willing to commit such interests to any ordinary man, to any one of whose integrity or ability we had a doubt. But it was done-with fear and trembling by some, by others with the confidence of faith. He took the stump. I doubt whether any man ever worked harder. He gave his whole soul to the work. Wherever he went he secured favor with the people, and he was elected... It was not a figure of speech that Governor Grimes made Iowa Republican, and allied it with the loyal States.

An article entitled "The Development of Party Organization in Iowa," by Prof. John W. Gannaway, of Grinnell, educator, writer and legislator, appearing in the Iowa Journal of History and Politics, Vol. I, No. 4, pp. 493524, states on p. 516 the following:

The advent of the slavery question into Iowa politics gave a second and even greater impetus to party activity. Although it meant, eventually, the division of one party and the dissolution of the other, no change in the form of their organizations was due to its introduction. The Democratic party was inclined to be pro-slavery in its sympathies although 
many of its members were opposed to slavery extension and united with the Whigs in 1856 to organize the new Republican party. The Whigs were largely anti-slavery men, and as the interest in the subject grew, were able to increase their strength until, in 1854, under the leadership of James W. Grimes they for the first time elected their State ticket. Opposition to Douglas's Nebraska Bill was the keynote of this campaign, and carried the State for the Whigs by nearly two thousand majority.

During these two years a new alignment of the parties was being made in most of the northern States. The opponents of slavery extension were coming together upon this single issue and organizing the Republican party to make their opposition effective. This movement met a cordial response from the anti-slavery people of Iowa. Immediately after the election of 1855 the plans for the organization of the Republican party were made, and by the first of the next year the time was ripe for a public announcement. In the issue of January 14, 1856, of the Muscatine Journal is found the following call which was written by Governor Grimes, although that fact was not made known at the time:

\section{To THE Citizens of Iowa}

Believing that a large majority of the people of Iowa are opposed to the political principles of the present administration, and to the introduction of slavery into the territory now free, and also that made free by the compromise of 1820; and that the party, styling itself the "Democratic party", are striving to make slavery a great national institution, contrary to the principles laid down in the Declaration of Independence and the Constitution, as taught by the fathers of the Republic; we would call upon all such free citizens to meet in convention, at Iowa City on the 22nd of February, for the purpose of organizing a Republican party, to make common cause with a similar party already formed in several other states of the Union.

Jan. 3rd, 1856.

Many Citizens

Thus, it would appear that the Grimes nomination and the following campaign and election in 1854 became the turning point politically in Iowa and that during Mr. Grimes' term as governor, the groundwork was laid for organization of the Republican party in the state, in which movement he was the aggressive leader, but the actual organization of the party in the state did not materialize until February of 1856. 
Copyright of Annals of Iowa is the property of State of Iowa, by \& through the State Historical Society of Iowa and its content may not be copied or emailed to multiple sites or posted to a listserv without the copyright holder's express written permission. However, users may print, download, or email articles for individual use. 